\title{
ENHANCING STUDENT'S READING EXPERIENCE USING TASK-BASED FLIPPED CLASSROOM IN READING COURSE
}

\author{
Risa Mufliharsi ${ }^{1}$, Ilza Mayuni ${ }^{2}$, Nuruddin ${ }^{3}$ \\ ${ }^{1,2,3}$ Program Pascasarjana, Universitas Negeri Jakarta \\ ${ }^{1}$ RisaMufliharsi_9906917002@mhs.unj.ac.id
}

\begin{abstract}
Abstrak
Flipped classroom merupakan model pembelajaran baru yang didukung pembelajaran untuk menggambarkan integrasi komponen tradisional (di dalam kelas) dan di luar kelas (persiapan dan tindak lanjut) pengetahuan dan internalisasi pengetahuan. Penelitian ini bertujuan untuk mendeskripsikan mata kuliah membaca berbasis tugas perguruan tinggi Indonesia melalui model kelas terbalik. Kajian tersebut dikontekstualisasikan dalam pengajaran Bahasa Indonesia melalui model Flipped Classroom. Rancangan penelitian ini melibatkan analisis deskriptif melalui kuesioner, dan wawancara mendalam. Temuan menunjukkan bahwa metode ini memiliki dampak positif pada pemahaman mahasiswa pada Mata Kuliah membaca di Pemahaman Membaca. Selain itu, penelitian ini memberikan beberapa wawasan pedagogis dan penelitian yang akan datang.
\end{abstract}

Kata Kunci: Flipped Classroom; Sistem Manajemen Pembelajaran; Pengajaran Bahasa Berbasis Tugas; Pemahaman Membaca; Kelas Membaca

\begin{abstract}
Flipped classroom is a new teaching model supported learning to design an integrated of traditional (in-class) and out-of-class components (preparation and follow up) the knowledge and internalizing the knowledge. The present study aims to describe task-based of reading course of Indonesian college through flipped classroom model. The study is contextualized in teaching English as a foreign language through the Flipped Classroom model. The design of the study involves descriptive analysis through questionnaires. The findings indicated that this method had positive impact on students' understanding of reading comprehension materials. Besides, this study provided some pedagogical insights and future research.
\end{abstract}

Keywords: Flipped Classroom; Learning Management System; Task-Based Language Teaching; Reading Comprehension; Reading Course

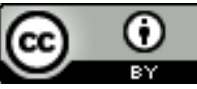

Creative Commons Attribution 4.0 International (CC BY 4.0)

\section{INTRODUCTION}

Flipped Classroom has been adapted in many aspects of higher education programs, especially during the COVID-19 era (Tang et al., 2020). Both students and lecturers face teaching and learning activities through technology. As one of the popular learning models, Flipped Classroom learning can guide students to learn independently 
to do some tasks that have been designed by the lecturer (Mohamed \& Lamia, 2018). The lecturer also engages the students through other learning activities such as requiring some videos or text that should be read, solving problems, discussion, hands-on activities, and guidance (Hao, 2016). The materials such as videos, power points, authentic tasks display in the application of modern educational technology can be accessed by students every time and everywhere before in class (Flaherty \& Phillips, 2015).

As its effectiveness in many subjects, only a few studies discuss about specific platforms that can be implemented in applying the Flipped Classroom. The platform of flipped classroom directly influenced the effectiveness of teaching and learning process especially in preparing students' background knowledge before in-time classroom (preclass phase)(Shibukawa \& Taguchi, 2019). The present study applied flipped classroom model through Learning Management System (LMS). By using LMS, the lecturer can manage the learning mechanism by developing course content and tests' threshold (Louhab et al., 2020). Besides, as machine learning has a significant role in the educational sector, LMS can perform a cognitive analysis based on set input data for both students and lecturers. Thus, LMS can play a vital role in the learners' community before, during, and after instructions because it can reduce lecturers' manual tasks (Al-masri \& Al-Assaf, 2020). LMS is a part of lecturer-designed e-learning systems that work as advance organizers in online learning to independently activate students' processes (Elfeky et al., 2020). The purpose of using the learning Management system from students' benefits is to learn independently using teaching materials in the form of text or video to maintain his understanding (Pramita et al., 2018). Besides, there are some changes in students' behaviors and characteristics because of their needs and weaknesses in accessing Learning Management System before learning with the lecturer (AlJarrah et al., 2018).

Therefore, the lecturer, viewed as a facilitator who supports successful learning, should enable access to information that students need through LMS. Through an asynchronous student-centered learning environment, the student will get the opportunity to reflect on their learning (Bachelor, 2017). It is an appropriate platform that support strategy and purposes of students' learning in pre-class, which can be developed during class in-depth and strengthen students' understanding through communicative activities. In this study, the writer designed task-based language teaching approach to improve students' reading skills. Task-Based Language Teaching commonly used to increase some skills English language teaching (Murtiningrum, Rr. Conny Riana Dewi, 2020). By combining two perspectives of Task-Based Language Learning and Flipped Classroom in a Learning Management System, students will be ready to enhance their understanding during reading course.

Based on the rationales above, there are some questions that are guided the whole part of the study (1) How is the process of task-based flipped classroom in Reading Course? and (2) How about students' reading experience in implementing Task-Based Flipped Classroom of reading course?

Reading course, to improve students' reading skills, lecturer needs more actions since preparing the lesson plan until conducting the evaluations. In this recent study, the author designed integrative reading strategies that developed by activating lower-level strategies (automatic linguistic processes) and higher-level strategies (comprehension processes from readers' ability to make inference, activate background knowledge, and structure knowledge) (Kuzborska, 2018). The course would be designed interactively that required the interaction activities. 


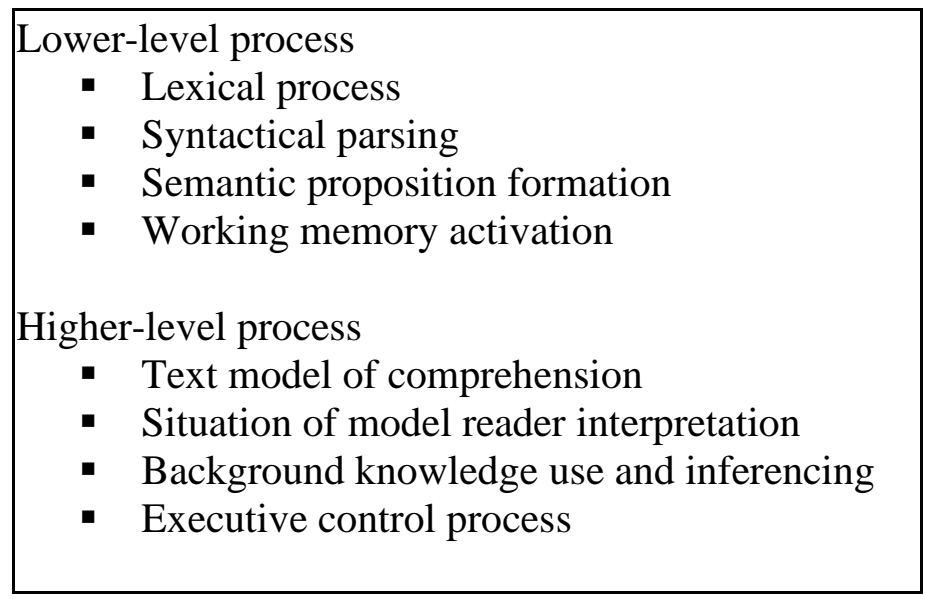

Figure 1 Cognitive Processes in Reading Comprehension adapted by (Grabe, William and Stoller, 2013)

Therefore, it is needed for lecturer to design teaching and learning approach to facilitate students' processes during reading course because there are many processes that should be comprehended by students to achieve the reading skills.

Task-based flipped classroom teaching model, as a type of instruction that utilizes tasks as a unit and practice in communicative manners, the task impacts students' input linguistic knowledge and large amounts of output in ELT skills (Wang \& Liu, 2018). In other words, the task reflects an activity in which a person engages to reach an objective and requires language use. The task is mentioned in planning (syllabus) and push the students to involve doing the task to perform the target task during instruction that focuses on meaningful learning (Schrooten, 2006).

Task-based language teaching has typical task circle frameworks, consisting of three steps: pre-task, task process, and post-task (Ellis, 2017). The pre-task phase introduces a new topic or theme of the task and asks the students with well-organized context structure and language forms, fixing up the model of what and how they will be asked to implement it. The task process represents how tasks given in the previous phase are performed and showed communicatively by students (by presenting, telling stories, writing). The Post-task phase mainly focuses on self-reflections handling the tasks (student's process of establishing the task individually, peer evaluation for teamwork result) and teacher evaluation based on comments, language focus, and in-class presentation (Chen \& Wang, 2019). In online terms, the circles can implement into a medium that can be designed more flexibly, not limited only to face-to-face learning. Using technology as a supporting tool, TBLT requires students to input nature and timing the form through more activities in various pedagogic procedures to develop student's attention to solve their linguistic problems and arise in communication. Simultaneously, the output requires the communicative task to achieve the outcome of activities in productive skills (in speaking and writing process)(Callender, 2017). Consequently, it needs a compatible approach as a medium for learning and interactive online teaching and learning activities.

In analysing and designing strategies of students' comprehension of reading course through online learning, students' tasks were arranged systematically for introducing the materials through pre-class activities to eliminate their pressures in facing difficulties during learning in face-to-face class because the comprehension phase has 
passed before the course (e.g. grammar exercise, unfamiliar vocabulary test, and so on.) in flipped classroom phase. Therefore, students can briefly review their difficulties or confusion (Tonkin et al., 2019). Flipped classroom phases also supported students' engagement in reading materials through students' self-directed learning pace before and after teaching and learning process outside real-time class (Tonkin et al., 2019).

Therefore, the current study is designed to explore the platform of flipped classroom model and its effect on EFL reading course to activate students' communicative competence. As a platform, LMS is seen as innovative tool that applies software application and web-based technology to create, track, distribute, and manage teaching learning online-based types (Elfeky et al., 2020). In other words, lecturers can develop students' learning process creatively accordance with their needs. For many reasons, the features of LMS have been upgraded according to purposes of learning, such as, an interactive communicative tool for lecturer-students through face-to-face meetings, chats, group discussion which integrate pedagogical and administrative online tools (Kasim \& Khalid, 2016). These processes involved personalized and collaborative learning, which connects students to their classmates and lecturers.

\section{RESEARCH METHOD}

This study describes the broad process of Task-Based Flipped Classroom in Active Reading class of private pedagogy university in Indonesia that was contextualized in EFL study. There were 179 participants of sophomore pre-service EFL students, whose determined in B2 level of CEFR. The students had never experienced FC learning model.

\section{Design and Procedure}

The primary materials are derived from RPS of Active Reading Class that are arranged in B2 CEFR level from many sources such as the book written by S. M. Beatrice \& Linda, J. which titled Advanced Reading Power: Extensive Reading, Vocabulary Building, Comprehension Skills, Reading Faster Reading Power. The book of Cambridge English First: First Certificate in English (FCE) CEFR Level (B2)_Handbook for Teacher.Cambridge-UK that written by Randi Reppen and Deborah Gordon. Besides, the book is written of D. M., Spears, \& Spears, D. M. titled Improving Reading Skills: Contemporary readings for college students. The last, the book is written by J. Taylor \& Wright, J in 2017 that titled IELTS Advantage Reading Skills: A Step-by-step Guide to a High IELTS Reading Score. Besides the book, the writers took some videos are taken by some sources from Youtube for videos and also websites.

Table 1 Sample of Task-Based Flipped Classroom of Learning Activities Throughout Semester

\begin{tabular}{|c|c|c|c|}
\hline Weeks & Lessons & Online $75 \%$ & Virtual $25 \%$ \\
\hline 2,3 & \begin{tabular}{ll}
\multicolumn{2}{l}{ Previewing } \\
$-\quad$ & Previewing of \\
passage \\
$-\quad$ Previewing of \\
paragraph \\
$-\quad$ Previewing of \\
Reading Text
\end{tabular} & \begin{tabular}{ll}
\multicolumn{2}{l}{ Pre-Class: } \\
- & Introducing Key Concept \\
- & Comprehend phases (Part A) \\
- & Comprehend phases (Part B) \\
- & Share 2 Care \\
In Class: \\
$-\quad$ Attendance \\
$-\quad$ Refresher \\
$-\quad$ Meet me \\
- & Connecting Ideas
\end{tabular} & $\begin{array}{l}\text { In Class virtually: } \\
\text { Meet me } \\
\text { - Review of learning } \\
\text { materials } \\
\text { - Both Lecturer and } \\
\text { students review of } \\
\text { learning activities in } \\
\text { LMS } \\
\text { Interactive Discussion } \\
\text { virtually }\end{array}$ \\
\hline
\end{tabular}




\section{- $\quad$ Thread of Discussion \\ - Your Turn \\ - Reflection}

Post Class: (additional)

Assignment

- Speed reading test through wWw.freespeedreading.com
Interaction (peer gap noticing)

Collaborative presentation

- Feedback

Lecturer-students

Lecturer-students feedback

Table 1 provides the weeks of teaching learning activities that divided into 6 broad materials, which are divided into 3 sub-topics of each. More than $75 \%$ of students' attendance was allocated for online class because the larger portion of the classroom activities were conducted online, while $25 \%$ was for doing interaction with lecturer and other students virtually through Google Meet or zoom.

The study drew on multiple sources of data, such as questionnaires, classroom's observation, and lecturers and students' interviews. The questionnaires are students' learning experience in reading class.

\section{RESULT AND DISCUSSION}

\section{Result}

\section{RQ 1 How is process of task-based flipped classroom in Reading Course?}

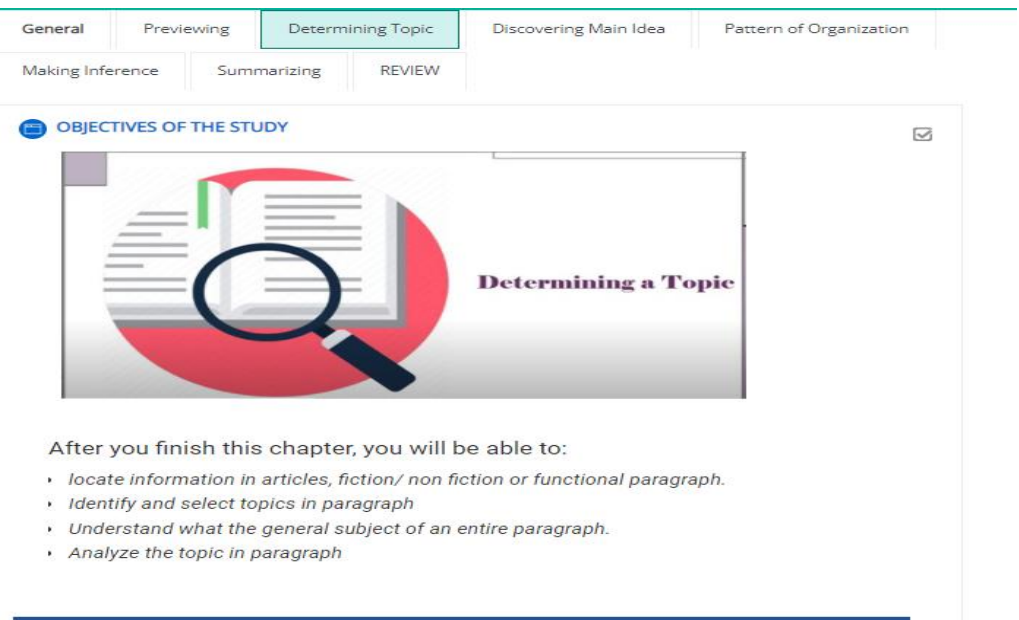

Figure 2 LMS Display

\section{Pre-Task of Task-Based Flipped Classroom Stage}

Pre-task activity has been set to introduce the broad materials to students systematically. In this phase, lecturer also designed objective of each reading materials (see figure 2). The purpose of this task is introducing new topic, preparing students' wellorganized context structures, comprehending the materials through context structure and forms of language, and setting how students will be required to carry out the task in LMS. In pre-task, the lecturer optimized students' reading knowledge through structured activities through videos, key concepts of materials, quizzes, and students' sharing through written activities. The task enabled the students to engage students' insights or perceptions through LMS features. 
During Task of Task-Based Flipped Classroom Stage

During task's orientation was designed to motivate and improve students' understanding and comprehension through reading courses. In maximizing the output of students' reading comprehension progress in real-time class, students were prepared to communicate through oral and written activities. The activities were consisted by many information gaps, such as: questions and answers of lecturer and students through chats features, virtual meeting, presentation of individual or group, and groups' discussion. These processes asked lecturer to facilitate guidance, monitoring, and immediate affirmation constantly.

\section{Post-Task of Flipped Classroom Stage}

This task's purpose provided students' individual report to let the lecturer evaluate his or her students' reading comprehension through scores.

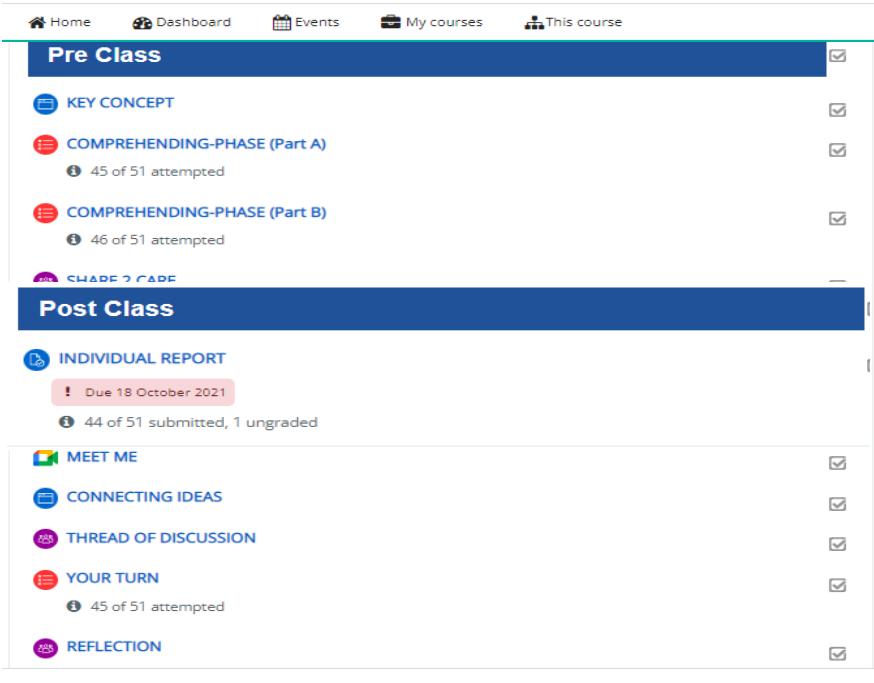

Figure 3. LMS Tasks for Active Reading Subject

RQ2. Students' reading experience in implementing Task-Based Flipped Classroom of Reading Course

Students' attitude in Reading Course was measured by students' reading experience scales consisted of enjoyment, cognitive involvement, interest, comprehensibility, and vividness (Link et al., 2021). Table 2 provides students' reading course demography. 
Table 2 Students' Active Reading Course Demography

\begin{tabular}{cccc}
\hline \multicolumn{2}{c}{ Demography Variables } & Frequency & $\begin{array}{c}\text { Percentage } \\
(\mathbf{\%})\end{array}$ \\
\hline Gender & Male & 15 & 18,5 \\
& Female & 66 & 81,5 \\
Age & $16-19$ Years Old & 26 & 32,1 \\
& $20-24$ Years Old & 52 & 64,2 \\
\multirow{4}{*}{ Profession } & $25->$ 25 Years Old & 3 & 3,7 \\
& Full-time student & 57 & 70,4 \\
& Part-Time Job & 20 & 24,7 \\
Marital Status & Having Permanent Job & 4 & 4,9 \\
& Married & 2 & 2,5 \\
& Unmarried & 79 & 97,5 \\
\hline
\end{tabular}

Table 2 showed that most of Active Reading course consisted of female students in pre-adult age. Most of students were full-time college students means that they would have enough time to practice more in outside class and engage in Active Reading LMS. Besides, most of them are unmarried, so they didn't have limitation to collaborate with their classmates through all of the processes in reading task through LMS.

Table 3 Students' Reading Experience through LMS

\begin{tabular}{|c|c|c|c|c|c|c|c|}
\hline \multirow[t]{2}{*}{ Reading Scales } & \multirow[t]{2}{*}{ Item of Questions } & \multicolumn{5}{|c|}{ Students' Responses } & \multirow{2}{*}{$\begin{array}{l}\text { The } \\
\text { Highest } \\
\text { Category }\end{array}$} \\
\hline & & 1 & 2 & 3 & 4 & 5 & \\
\hline \multirow[t]{5}{*}{ Enjoyment } & $\begin{array}{l}\text { I enjoyed learning in Reading class } \\
\text { because I got knowledge and also } \\
\text { learning experiences through } \\
\text { synchronous (LMS) and asynchronous } \\
\text { (G-meet/zoom) }\end{array}$ & 0 & 1 & 10 & 49 & 21 & Agree \\
\hline & $\begin{array}{l}\text { Doing Pre-Class task in LMS made me } \\
\text { frustrated because the material is } \\
\text { difficult }\end{array}$ & 2 & 12 & 36 & 17 & 14 & Neutral \\
\hline & $\begin{array}{l}\text { I enjoyed Pre- Class task because it } \\
\text { facilitated me to practice and develop my } \\
\text { reading skills and knowledge }\end{array}$ & 0 & 5 & 11 & 41 & 24 & Agree \\
\hline & $\begin{array}{l}\text { I like In-Class tasks because I can } \\
\text { cooperate with my classmates and } \\
\text { getting feedback from my lecturer }\end{array}$ & 0 & 0 & 22 & 35 & 24 & Agree \\
\hline & $\begin{array}{l}\text { I am satisfied with my learning } \\
\text { experience because it's different with } \\
\text { previous reading class }\end{array}$ & 0 & 1 & 19 & 39 & 22 & Agree \\
\hline \multirow[t]{3}{*}{$\begin{array}{l}\text { Cognitive } \\
\text { Involvement }\end{array}$} & $\begin{array}{l}\text { Pre-Class activities in LMS improve my } \\
\text { background knowledge related to } \\
\text { Reading materials }\end{array}$ & 0 & 1 & 14 & 36 & 30 & Agree \\
\hline & $\begin{array}{l}\text { The use of video and key concept in } \\
\text { LMS helped me to explore and give } \\
\text { some insight in answering questions in } \\
\text { LMS }\end{array}$ & 0 & 1 & 13 & 36 & 31 & Agree \\
\hline & $\begin{array}{l}\text { Some Interactive Tasks (Share2care; } \\
\text { Refresher; Discussion; and Reflection) } \\
\text { in LMS were valuable to help me getting } \\
\text { more understanding in Reading }\end{array}$ & 0 & 1 & 19 & 35 & 26 & Agree \\
\hline
\end{tabular}




\begin{tabular}{|c|c|c|c|c|c|c|c|}
\hline \multirow[t]{5}{*}{ Interest } & $\begin{array}{l}\text { The lecturer supported and motivated me } \\
\text { to be active in doing some tasks through } \\
\text { synchronous (LMS) and asynchronous } \\
\text { (G-meet/zoom) }\end{array}$ & 0 & 2 & 9 & 33 & 37 & $\begin{array}{l}\text { Strongly } \\
\text { Agree }\end{array}$ \\
\hline & $\begin{array}{l}\text { The tasks of Reading through Pre-Class, } \\
\text { In-Class, and Post-Class stimulated my } \\
\text { curiosity for doing the best in this class }\end{array}$ & 0 & 3 & 19 & 40 & 19 & Agree \\
\hline & $\begin{array}{l}\text { I keep enthusiastic in this class because I } \\
\text { can communicate with lecturer and } \\
\text { classmates to discuss about my } \\
\text { weaknesses in Reading paragraph/text }\end{array}$ & 0 & 4 & 20 & 40 & 17 & Agree \\
\hline & $\begin{array}{l}\text { Learning through LMS supported myself } \\
\text { to be active independently to explore } \\
\text { reading materials }\end{array}$ & 0 & 3 & 11 & 38 & 29 & Agree \\
\hline & $\begin{array}{l}\text { I'm interested taking a part of each tasks } \\
\text { in LMS because having more time to } \\
\text { prepare my answers. }\end{array}$ & 0 & 5 & 19 & 32 & 25 & Agree \\
\hline \multirow[t]{4}{*}{$\begin{array}{l}\text { Comprehensibi } \\
\text { lity }\end{array}$} & $\begin{array}{l}\text { Most of reading materials were } \\
\text { administrated in visual and text. So, it's } \\
\text { easy to be learned independently }\end{array}$ & 0 & 1 & 16 & 44 & 20 & Agree \\
\hline & $\begin{array}{l}\text { Combination of some tasks through } \\
\text { synchronous (LMS) and asynchronous } \\
\text { (G-meet/zoom) help me to build } \\
\text { understanding about reading materials. }\end{array}$ & 0 & 1 & 13 & 44 & 23 & Agree \\
\hline & $\begin{array}{l}\text { Learning through LMS facilitated me to } \\
\text { get appropriate feedback from lecturer } \\
\text { about my improvement in doing tasks }\end{array}$ & 0 & 2 & 18 & 41 & 20 & Agree \\
\hline & $\begin{array}{l}\text { Most of quizzes and assignments } \\
\text { developed my understanding and } \\
\text { strategy in reading paragraphs/texts }\end{array}$ & 0 & 0 & 13 & 40 & 28 & Agree \\
\hline \multirow[t]{4}{*}{ Vividness } & $\begin{array}{l}\text { The use of video and reading key } \\
\text { concepts in Pre-Class help me to } \\
\text { familiarize the reading materials }\end{array}$ & 0 & 1 & 12 & 37 & 31 & Agree \\
\hline & $\begin{array}{l}\text { In LMS, most of paragraphs and texts } \\
\text { were structured clearly to support } \\
\text { relevance information in each materials }\end{array}$ & 0 & 0 & 16 & 50 & 15 & Agree \\
\hline & $\begin{array}{l}\text { Through LMS, I can get information and } \\
\text { build some strategies in doing tasks } \\
\text { independently and cooperatively with } \\
\text { my group }\end{array}$ & 0 & 0 & 15 & 42 & 24 & Agree \\
\hline & $\begin{array}{l}\text { Reflection feature in LMS help me to } \\
\text { improve my knowledge and skills in } \\
\text { reading from my improvement and } \\
\text { weaknesses through learning activities }\end{array}$ & 0 & 0 & 15 & 37 & 29 & Agree \\
\hline
\end{tabular}

I can develop my understanding in $\begin{array}{lllllll}0 & 0 & 15 & 40 & 26 & \text { Agree }\end{array}$ Reading class through some tasks through knowledge and also learning experiences through synchronous (LMS) and asynchronous (G-meet/zoom)

The combination of learning tasks in this class helped me to construct Reading knowledge and skill and improve my communicative skills through oral and written activities

The lecturer supported and motivated me (G-meet/zoom) curiosity for doing the best in this clas I keep enthusiastic in this class because communicate with lecturer and $\begin{array}{llllll}0 & 1 & 14 & 42 & 24 & \text { Agree }\end{array}$ 
that learning through LMS in reading course gave them enjoyment, cognitive involvement, interest, comprehensibility, and framing vividness better than before. It was proven by descriptive analysis in table 4 .

Table 4 Descriptive Statistic of Reading Experience

\begin{tabular}{|c|c|c|c|c|c|}
\hline \multicolumn{6}{|c|}{ Descriptive Statistics } \\
\hline & $\mathrm{N}$ & Minimum & Maximum & Mean & Std. Deviation \\
\hline Reading & 81 & 3 & 5 & 4.00 & .524 \\
\hline Valid N (listwise) & 81 & & & & \\
\hline \multicolumn{6}{|l|}{ Reliability Statistics } \\
\hline Cronbach's Alpha & & & & f Items & \\
\hline .944 & & & & 23 & \\
\hline
\end{tabular}

\section{Discussion}

From the results, some processes happened and impacted students' output specially to engage students to enrich students' communication in reading course.

\section{Pre-class focussed on developing students' background knowledge}

Pre-class phase implemented lower-level process (example: lexical process of language, syntactical parsing of paragraph, semantic proportion of paragraph, and working memory activation through similar task) (Grabe, William and Stoller, 2013). It started with Key Concept for watching the video and summary of material as pre-task to frame the concepts of materials that should be learned. The videos were designed by the lecturers in 10-15 minutes. Next, Comprehending-phases which were consisted by quizzes of two parts grouped-based on assessments' characteristics. The last task is Share 2 Share that were consisted by students' perceptions of their activities in pre-class phase. These processes supported pre-task students' exploration to draw students' schema (developing students' understanding through videos and key concept) and constructing students' Zones of Proximal Development (ZDP) (Chen \& Wang, 2019)

\section{In-class focussed on framing students' communicative activities}

In-class phase implemented students' task performances through communicative activities in real-time lecture's schedule to engage students to explore their previous understanding. It indicated that lecturer should develop learning culture effectively (Chavangklang \& Suppasetseree, 2020). Through synchronous activities, both lecturer and students could communicate in Whatsapp application or Zoom and G-meet to get along collaborating, discussing, or solving the information gap from the previous task in pre-class. After checking the students' attendance through G-form, the lecturer asked student to refresh their previous ideas that they have got from pre-class. Through refresher, the lecturer stimulated her students' background knowledge from two or three broad questions that requiring students' explanation to find out each students' insights. In Meet Me, the lecturer proved to give students more opportunity during classroom activities and bridge the classroom communication between lecturer-students and each of students through virtual class (G-Meet/Zoom). This condition brought positive response during learning process to maximize their understanding in reading course (Prasetyaningrum, 2018). In Connecting Ideas, the lecturer confirmed the students' 
perception through video and connect the pre-class ideas to further materials as information gap for base to next task Thread of Discussion. Thread of Discussion could be presented into groups or individual task to support doing higher-level process to understand the text model clearly, draw model reader interpretation, compose inferencing, and construct executive control process carefully (William Grabe, 2008). The last, Reflection tried to ask students to be aware about their learning processes through all phases in pre-class and in-class. It supported motivation for students to develop their reading skills, persist and make strong effort to overcome their limitation (Grabe, 2009; Tavakoli et al., 2019)

\section{Post-class focused to evaluate students' achievement through all task}

Post-class administered students' assignment efficiently and effectively. Furthermore, students were intended not entering class. Individual Report could be subjective or objective test to measure student's achievement in reading course.

\section{CONCLUSION}

This study only focusses on description of the implementation of task-based language teaching as strategy in improving students' reading skills. Through communicative task using flipped classroom in pedagogy EFL reading course context, students will engage to structured-materials focusly. The limitation of this study is the limitation of exploring students' effectiveness of task-based flipped classroom through empirical test to enrich this study. However, the questionaire can give broad view about students' reading experience to find out students' engagement through reading course.

There are some implications for future research. First, preparation is needed not only for lecturer who designed the materials, but also the students' readiness to learn about the materials especially when they found difficult ones (unfamiliar vocabulary, lack of grammar, etc). They have more time to watch videos at their own pace and do comprehending quiz freely without feeling anxiety. The last, even the students can learn independently in LMS, they still need to engage lecturer's guidance as their confirmation of their perceptions. It indicates that both lecturer's corrective feedback and task repetition are needed to familiarize students with task procedures, expectation, and maximizing the efficiency of arranging classtime effectively. The combination of well preparation in LMS and lecturer's corrective feedback in pre-class and in-class phases will influence student's report in post class.

\section{REFERENCES}

AlJarrah, A., Thomas, M. K., \& Shehab, M. (2018). Investigating temporal access in a flipped classroom: procrastination persists. International Journal of Educational Technology in Higher Education, 15(1), 1-18. https://doi.org/10.1186/s41239017-0083-9

Al-masri, A. N., \& Al-Assaf, Y. (2020). Sustainable sevelopment and social responsibility (Vol. 2). http://link.springer.com/10.1007/978-3-030-32902-0

Bachelor, J. W. (2017). Increasing student communication and spontaneous language use in the L2 classroom: A careful consideration of the flipped classroom model. The TFLTA Journal, 6(1998), 5-11.

Callender, W. A. (2017). Teaching and learning in secondary schools. Using RTI in Secondary Schools: A Training Manual for Successful Implementation, 33-76. https://doi.org/10.4135/9781452290522.n3 
Chavangklang, T., \& Suppasetseree, S. (2020). Enhancing Thai EFL university students' reading comprehension through a flipped cooperative classroom. PEOPLE: International Journal of Social Sciences, 4(3), 238-261. https://doi.org/10.20319/pijss.2018.43.238261

Chen, S., \& Wang, J. (2019). Effects of task-based language teaching (TBLT) approach and language assessment on students' competences in intensive reading course. English Language Teaching, 12(3), 119. https://doi.org/10.5539/elt.v12n3p119

Elfeky, A. I. M., Masadeh, T. S. Y., \& Elbyaly, M. Y. H. (2020). Advance organizers in flipped classroom via e-learning management system and the promotion of integrated science process skills. Thinking Skills and Creativity, 35, 100622. https://doi.org/10.1016/j.tsc.2019.100622

Ellis, R. (2017). Position paper: Moving task-based language teaching forward. Language Teaching, 50(4), 507-526. https://doi.org/10.1017/S0261444817000179

Flaherty, J. O., \& Phillips, C. (2015). Internet and higher education the use of flipped classrooms in higher education: A scoping review the Internet and Higher Education, 25, 85-95. https://doi.org/10.1016/j.iheduc.2015.02.002

Goedhart, N. S., Blignaut-van Westrhenen, N., Moser, C., \& Zweekhorst, M. B. M. (2019). The flipped classroom: Supporting a diverse group of students in their learning. Learning Environments Research, 22(2), 297-310. https://doi.org/10.1007/s10984-019-09281-2

Grabe, W. (2008). Reading in a second language moving theory to practice.pdf. Cambridge University Press.

Grabe, W. (2009). Reading in a second language: Moving from theory to practice by Grabe, William. In The Modern Language Journal (Vol. 95, Issue 1, pp. 143144). Cambridge University Press. https://doi.org/10.1111/j.15404781.2011.01151.x

Grabe, W., \& Stoller, F. L. (2013). Teaching and researching reading (C. N. C. and D. R. Hall (ed.); Second). Routledge.

Hao, Y. (2016). Exploring undergraduates' perspectives and flipped learning readiness in their fl ipped classrooms. Computers in Human Behavior, 59, 82-92. https://doi.org/10.1016/j.chb.2016.01.032

Kasim, N. N. M., \& Khalid, F. (2016). Choosing the right learning management system (LMS) for the higher education institution context: A systematic review. International Journal of Emerging Technologies in Learning, 11(6), 55-61. https://doi.org/10.3991/ijet.v11i06.5644

Khezrlou, S. (2019). Task repetition and corrective feedback: The role of feedback types and structure saliency. English Teaching and Learning, 43(2), 213-233. https://doi.org/10.1007/s42321-019-00025-2

Kuzborska, I. (2018). Interactive reading strategies. The TESOL Encyclopedia of English Language Teaching, 1-7. https://doi.org/10.1002/9781118784235.eelt0475

Link, E., Henke, J., \& Möhring, W. (2021). Credibility and enjoyment through data? Effects of statistical information and data visualizations on message credibility and reading experience. Journalism Studies, 22(5), 575-594. https://doi.org/10.1080/1461670X.2021.1889398

Louhab, F. E., Bahnasse, A., Bensalah, F., Khiat, A., Khiat, Y., \& Talea, M. (2020). Novel approach for adaptive flipped classroom based on learning management system. Education and Information Technologies, 25(2), 755-773. https://doi.org/10.1007/s10639-019-09994-0 
Mohamed, H., \& Lamia, M. (2018). Implementing flipped classroom that used an intelligent tutoring system into learning process. Computers and Education, 124, 62-76. https://doi.org/10.1016/j.compedu.2018.05.011

Murtiningrum, R. C. R. D., Rafli, Z., \& Purbaini, A. (2020). Penerapan metode task-based learning untuk meningkatkan keterampilan menulis surat bisnis bahasa inggris. Deiksis, 12(02), 220-228.

Pramita, M., Sukmawati, R. A., \& Sari, D. P. (2018). The implementation of flipped classroom assisted by learning management system for numerical method courses. 274, 158-162. https://doi.org/10.2991/iccite-18.2018.36

Prasetyaningrum, D. I. (2018). Improving agriculture students' reading comprehension through task-based language teaching (TBLT). EnJourMe (English Journal of Merdeka): Culture, Language, and Teaching of English, 3(1). https://doi.org/10.26905/enjourme.v3i1.2202

Schrooten, W. (2006). Task-based language education (K. Van den Branden (ed.); Vol. 4, Issue 1). Cambridge University Press.

Shibukawa, S., \& Taguchi, M. (2019). Exploring the difficulty on students' preparation and the effective instruction in the flipped classroom: A case study in a physiology class. Journal of Computing in Higher Education, 31(2), 311-339. https://doi.org/10.1007/s12528-019-09220-3

Tang, T., Abuhmaid, A. M., Olaimat, M., Oudat, D. M., Aldhaeebi, M., \& Bamanger, E. (2020). Efficiency of flipped classroom with online-based teaching under COVID-19. Interactive Learning Environments, 1-12. https://doi.org/10.1080/10494820.2020.1817761

Tavakoli, H., Lotfi, A. R., Biria, R., \& Wang, S. (2019). Effects of CALL-mediated TBLT on motivation for $\mathrm{L} 2$ reading. Cogent Education, 6(1), 1-21. https://doi.org/10.1080/2331186X.2019.1580916

Tonkin, K., Page, S., \& Forsey, M. (2019). Managing cognitive load with a flipped language class: An ethnographic study of the student experience. Foreign Language Annals, 52(3), 551-575. https://doi.org/10.1111/flan.12412

Wang, S., \& Liu, C. (2018). Task-based flipped classroom in chinese college EFL teaching: An empirical study in oral English course. International Journal of Contemporary Education, 1(1), 12. https://doi.org/10.11114/ijce.v1i1.3086 